\title{
Añtidermatophytic Activities of Nine (9) Essential Oils
}

\section{J.R. KUIATE ${ }^{*}$, S.P. KUATE ${ }^{1,2}$, N.E. KEMADJOU ${ }^{3}$, S. DJOKOUA ${ }^{3}$, F. ZIFACK ${ }^{3}$ AND J. FOKO}

${ }^{\prime}$ Department of Biochemistry, FS, University of Dschang, P.O. Box 67 Dschang, Cameroon.

${ }^{2}$ Department of Biochemistry, FS, University of Yaoundé, P.O. Box 812 Yaoundé, Cameroon.

${ }^{3}$ Department of Biochemistry, FS, University of Douala, P. O. Box 24157 Douala, Cameroon.

${ }^{4}$ Department of Plant protection, FASA, University of Dschang, P.O. Box 222 Dschang, Cameroon.

\begin{abstract}
The antidermatophytic activity of nine essential oils from 7 plants against 6 fungi was investigated. Fungistatic effect was observed for the oil of Coreopsis bonariensis $(2 \mathrm{mg} / \mathrm{ml})$, Laggera alata var alata $(1 \mathrm{mg} / \mathrm{ml})$ against Microsporum audouinii and for Cupressus lusitanica oil against Trichophyton mentagrophytes $(2 \mathrm{mg} / \mathrm{ml})$. Fungicidal effect was observed for the C. lusitanica (leaves) oil (2 $\mathrm{mg} / \mathrm{ml}$ ) against Trichophyton mentagrophytes, Erigeron floribundus (leaves) oil (1 $\mathrm{mg} / \mathrm{ml}$ ) against Candida albicans and for oil of the flowering ends of $C$. lusitanica against Trichophyton mentagrophytes at $1 \mathrm{mg} / \mathrm{ml}$. Finally, the essential oils of $C$. lusitanica were found to be the most a ctive while $M$. audouinii was the least resistant fungus.
\end{abstract}

Keywords: Antidermatophytic, essential oils.

\section{INTRODUCTION}

The treatment of skin diseases and especially dermatophytosis is mainly by synthetic drugs (polyenes, azoles and allylamines) [1]. These drugs are few in number and have a narrow safety margin. Some functional disorders like nephrotoxicity may result due to their administration [2]. This explains why researchers have recently been concentrating on the search for new plants derived substances with more activity and less toxicity. This interest for medicinal plants is well understood, taking into account the large population of the developing countries, which exclusively use these plants for treatment. In fact a ccording to the World Health Organization (WHO), this fraction of population is about $80 \%$ [3]. This orientation towards plants shows that the plants are potential reservoirs of efficient antimicrobial substances, which are biodegradable [4]. The essential oils that are more often, complex mixtures of components derived from aromatic plants could then be one of the possible sources. In this investigation, we describe the in vitro activity of nine essential oils against six (6) dermatophyte isolates, which are considered as a major cause of morbidity and mortality [5].

\section{EXPERIMENTAL}

\section{Plant material and isolation of essential oils}

The essential oils used in this study were obtained from Cupressus lusitanica Mill. (flowering ends), Erigeron floribundus (H.B. \& K.) Sch. Bip (leaves and flowers) and leaves of Coreopsis bonariensis, Coreopsis asperta, Laggera pterodonta Sch. Bip, L. alata (Sch. Bip ex Oliver var alata, L. alata var montana (table 1). These plants were harvested in and around the campus of the University of Dschang. All voucher specimens have been deposited at the Laboratory of plant Biology, Faculty of Science, University of Dschang. Fresh plant material $(1 \mathrm{~kg})$ was subjected to hydrodistillation for 8 hours. The oil was dried over anhydrous sodium sulfate and stored in refrigerator till usage.

\section{Screening for antifungal activity}

Six (6) fungal isolates, Trichophyton mentagrophytes 10a, Trichophyton mentagrophytes DL92, Trichophyton mentagrophytes var interdigitale $\mathrm{F} 120 \mathrm{~b}$, Trichophyton rubrum Ma2, Microsporum audouinii and Candida albicans isolated clinically, were used to establish the antifungal activity of essential oils. 
Table 1: Essential oils and tested fungi

\begin{tabular}{|c|c|c|}
\hline Essential oils & & Fungi \\
\hline Cupressus lusitanica & Flowering ends & $\begin{array}{l}\text { Trichophyton mentagrophytes } 10 \mathrm{a} \\
\text { Trichophyton mentagrophytes } \mathrm{DL} 92 \\
\text { Trichophyton mentagrophytes var interdigitale } \mathrm{F} 120 \mathrm{~b} \\
\text { Trichophyton rubrum } \mathrm{Ma} 2\end{array}$ \\
\hline Cupressus lusitanica & Leaves & $\begin{array}{l}\text { Trichophyton mentagrophytes } 10 \mathrm{a} \\
\text { Candida albicans }\end{array}$ \\
\hline Coreopsis bonariensis & Leaves & $\begin{array}{l}\text { Microsporum audouinii } \\
\text { Trichophyton mentagrophytes } 10 \mathrm{a}\end{array}$ \\
\hline Coreopsis asperta & Leaves & $\begin{array}{l}\text { Trichophyton mentagrophytes } 10 \mathrm{a} \\
\text { Trichophyton mentagrophytes } \mathrm{DL} 92\end{array}$ \\
\hline Laggera alata var alata & Leaves & Microsporum audouinii \\
\hline Laggera alata var montana & Leaves & $\begin{array}{l}\text { Microsporum audouinii } \\
\text { Trichophyton mentagrophytes DL92 }\end{array}$ \\
\hline Laggera pterodonta & Leaves & Trichophyton mentagrophytes DL92 \\
\hline Erigeron floribundus & Leaves & $\begin{array}{l}\text { Trichophyton mentagrophytes } 10 \mathrm{a} \\
\text { Candida albicans }\end{array}$ \\
\hline Erigeron floribundus & Flowers & $\begin{array}{l}\text { Trichophyton mentagrophytes } 10 \mathrm{a} \\
\text { Candida albicans }\end{array}$ \\
\hline
\end{tabular}

All the fungi were maintained on Sabouraud Dextrose Agar. The basic culture medium used for the assays was Sabouraud Dextrose Agar (SDA) supplemented with chloramphenicol. Final oil doses of $0.5,1$ and $2 \mathrm{mg} / \mathrm{ml}$ in the medium were obtained after dispersion of the essential oil in water containing Tween 20 . The concentration of Tween 20 in the medium did not exceed $3 \%$ and it was used as positive control. Thus, a precise volume of a stock solution $(0,1 \mathrm{~g} / \mathrm{ml})$ of essential oil was pipetted and added to sufficient volume of culture medium for $20 \mathrm{ml}$ so as to reach the desired concentration of the essential oil in the medium.

\section{Determination of the Effects of the essential oils on mycelial growth}

The technique used was similar to that described by Ngane [6]. The fungus was allowed to grow first on SDA for 7 days at $25 \pm 2{ }^{\circ} \mathrm{C}$ after which time a circular piece of fresh mycelium was transferred into petri dishes containing SDA with different essential oil doses. The petri dishes were incubated for 10 days at $25 \pm 2{ }^{\circ} \mathrm{C}$, during which the length of mycelium was measured every $24 \mathrm{~h}$. All culture media were done in triplicate. If no growth were observed after 10 days, the piece of mycelium was transferred on to oil free SDA in a petri dish and incubated at $25 \pm 2{ }^{\circ} \mathrm{C}$ in order to determine whether it was still viable. Minimum Inhibitory Concentration (MIC) was considered as the smallest oil concentration to inhibit mycelial growth. The mycelial growth $(\mathrm{Mg})$ and the percentage of inhibition (I \%) were respectively calculated from these relations:

$$
\begin{aligned}
\mathrm{Mg} & =\left(\theta_{1}-\theta_{2}\right) / 2-\theta_{0} \\
\mathrm{I} \% & =\left(\left(\theta_{\mathrm{t}}-\theta_{\mathrm{e}}\right) / \theta_{\mathrm{t}}\right) \times 100
\end{aligned}
$$

$\theta_{1}$ and $\theta_{2}$ are perpendicular diameter of mycelial growth, $\theta_{0}$ the diameter of the initial circular piece, $\theta_{t}$ the diameter of the mycelial growth of the negative control (petri dish without essential oil) and $\theta_{e}$ the diameter of the mycelial growth in a test petri dish.

\section{Statistical Analyses}

The means of the percentages of inhibition and the efficacy of essential oils were compared using analyses of variance taking into account both isolates and essential oil factors. At this effect, the SPSS 0.1 computer program was used. The differences at $\mathrm{p}<0.05$ were considered significant.

\section{RESULTS AND DISCUSSION}

The results obtained in this work are shown in table 2. From the results, it is evident that the tested essential oils possessed different antifungal activities. The difference in the activity varies with the type of fungi species. The difference in activity observed between the essential oil could be due to their chemical dissimilarities both quantitatively and qualitatively. 
Table 2: Effects of essential oils on various fungi isolates

\begin{tabular}{|c|c|c|c|c|c|}
\hline Fungi & Essential Oils & & 1 (not) & $\begin{array}{l}\mathrm{MIC} \\
(\mathrm{mg} / \mathrm{ml})\end{array}$ & Observations \\
\hline \multirow[t]{6}{*}{ T. mentaqggrophytes $10 \mathrm{a}$} & C. lusitanica & Leaves & $88.55^{b, c}$ & 2 & Fungicidal \\
\hline & C. lusitanica & Flowering ends & $90.32^{b}$ & 2 & Fungistatic \\
\hline & C. bonariensis & Leaves & $59.76^{\mathrm{g}}$ & $>2$ & - \\
\hline & C. asperta & Leaves & $75.65^{d}$ & $>2$ & - \\
\hline & E. floribundus & Leaves & $52.13^{\mathrm{h}}$ & $>2$ & - \\
\hline & E. floribundus & Leaves & $50.71^{\mathrm{h}}$ & $>2$ & - \\
\hline \multirow{5}{*}{ T. mentagrophytes DL92 } & C. lusitanica & Flowering ends & $82.12^{\mathrm{c}}$ & $>2$ & - \\
\hline & C. bonariensis & Leaves & $78.45^{\mathrm{d}}$ & $>2$ & \\
\hline & C. asperta & Leaves & $81.25^{\mathrm{c}}$ & $>2$ & \\
\hline & L. pterodonta & Leaves & $72.25^{\mathrm{e}}$ & $>2$ & \\
\hline & L. alata var montana & Leaves & $77.18^{\mathrm{d}}$ & $>2$ & \\
\hline \multirow[t]{3}{*}{ C. albicans } & C. lusitanica & Leaves & $6.60^{f}$ & $>2$ & \\
\hline & E. floribundus & Leaves & $95.08^{\mathrm{a}, \mathrm{b}}$ & 2 & Fungicidal \\
\hline & E. floribundus & Flowers & $83.43^{c}$ & $>2$ & \\
\hline \multirow[t]{3}{*}{ M. audouinii } & C. bonariensis & Leaves & $56.59^{8}$ & 2 & \\
\hline & L. alata var alata & Leaves & $92.16^{\mathrm{b}}$ & 1 & Fugistatic \\
\hline & L. alata var montana & Leaves & $100^{\mathrm{a}}$ & 0.5 & \\
\hline T. rubrum & C. bonariensis & Flowerings ends & $98.99^{\mathrm{a}}$ & 1 & \\
\hline $\begin{array}{l}\text { T.metagraphytes } \\
\text { var interdigitale } \mathrm{F} 120 \mathrm{~b}\end{array}$ & C. lusitanica & Flowering ends & $71.48^{\mathrm{e}}$ & $>2$ & \\
\hline
\end{tabular}

I: Percentages of inhibition followed by the same letter are not significantly different at $p=0.05 \mathrm{Mic}$ : Minimum inhibitory concentration.

Indeed, the essential oil of L. alata var montana is mainly constituted of dimethoxy-p-cymene (34\%) and epi- $\gamma$-endesmol (21.4\%) [7]. Those of leaves and flowers of $E$. floribundus are rich in limonene $(9.5 \%$ for leaves and $3.7 \%$ for the flowers) and in polyacetylated compounds like (E)-2-lachnophyllum ester $(23.7 \%$ for leaves and $3.4 \%$ for the flowers) [8]. The observed activities could be attributed to these major components while recognizing that this activity is often the result of the combined action (antagonism, synergy and potentiation) of all the constituents of an essential oil taking into consideration even those present in trace [9]. This is why, essential oil $L$. alata var montana inhibits $M$. audouinii at $100 \%$ compared 56.59 $\%$ for $C$. bonariensis on the same fungus.

On the other hand, the differences in susceptibility, which characterize the isolates of this study, could be due to their belonging either to different species or to different $v$ arieties for the same species (e.g T. mentagrophytes). Thus, they could have divergent genetic constitution. The highest susceptibility of T. rubrum (98.99 $\%)$ to the EO of flowering ends of $C$. lusitanica against $71.48 \%$ for $T$. mentagrophytes is a good illustration of this variation.
Also, the decrease in activity of the essential oils with time could be attributed to their volatility. On the o ther $h$ and, the increase of the a ctivity with the dose could be explained through their cumulative effect and abundant proportion of the active substance (s), which lead to the death of the fungus.

\section{CONCLUSION}

Essential oils used in this work possess antifungal activity against dermatophytes. The overall results show that $M$. audouinii is the most susceptible fungus whereas the essential oil of flowering ends of $C$. lusitanica is the most active.

\section{ACKNOWLEDGEMENT}

We thank the University of Dschang that partially supported this work financially, the Head of Department of the Plant Protection (FASA) and Ngo Téké Gerald who helped in the correction of this document. 


\section{REFERENCES}

[1] M.A. Ghannoum and L.B. Rice, Clinical Microbiological Review 2(4) (1999) 501.514 .

[2] W.E. Dismukes. Clinical Infections Diseases 30 (2000), 653-657.

[3] J.N. J. Eloff, of Ethnopharmacol. 60 (1997), 1-8.

[4] N. Kishore, J.P.N. Chansouria and N.K. Dubey. Phyreh 10 (1996), 453-455.

[5] J. Euzeby Cours de mycologie médicale comparée: Les mycoses des animaux et leurs relations avec les mycoses de l'homme, Vigot frères, Paris. 1969. p303

[6] A.R. Ngono Ngane. Contribution à l'étude des propriétés antifongiques et analyse phytochimique de cinq plantes médicinales camerounaises. Thèse de Doctorat Université de Reims, 1999. p196.

[7] J.R., Kuiate, J.M. Bessiere and Amvam Zollo, P.H. Flavour Fragr. J. 17 (2002), 105-108.

[8] J.R. Kuiate, T.A. Amfo, J. Foko, J.M. Bessiere, and Z.P.H. J. Amvam Essent. Oil Research, in press.

[9] J. Valnet, Aromatherapie: traitement des maladies par les plantes. $9^{\text {th }}$ edition. Librairie Maloine S A. Paris. 1980. p443.

[10] M.D. Martins, and J.H. Rex, New Horizons 4 (1996), 338-344. 